\title{
Understanding the physiological roles of the neuronal calcium sensor proteins
}

\author{
Robert D Burgoyne ${ }^{*}$ and Lee P Haynes
}

\begin{abstract}
Calcium signalling plays a crucial role in the control of neuronal function and plasticity. Changes in neuronal $\mathrm{Ca}^{2+}$ concentration are detected by $\mathrm{Ca}^{2+}$-binding proteins that can interact with and regulate target proteins to modify their function. Members of the neuronal calcium sensor (NCS) protein family have multiple non-redundant roles in the nervous system. Here we review recent advances in the understanding of the physiological roles of the NCS proteins and the molecular basis for their specificity.
\end{abstract}

Keywords: Calcium, Calcium-sensor, EF-hand, neuronal signalling, protein complex, protein structure

\section{Introduction}

Calcium has a major role in neurons as the trigger for neurotransmitter release [1,2]. In addition many other aspects of neuronal function are regulated by changes in intracellular free $\mathrm{Ca}^{2+}$ concentration. Rapid exocytosis of neurotransmitter-containing synaptic vesicles is activated by a local increase in $\mathrm{Ca}^{2+}$ concentration at the presynaptic active zone within $10 \mathrm{~s}$ of microseconds [3] through the action of the $\mathrm{Ca}^{2+}$ sensor synaptotagmin [4]. Other $\mathrm{Ca}^{2+}$-regulated events require more global changes in neuronal $\mathrm{Ca}^{2+}$ concentration, are activated over longer time scales and the changes can persist for minutes to days [5]. In part the specificity of the effects of $\mathrm{Ca}^{2+}$ on neuronal physiology is determined by the magnitude, kinetics and spatial localisation of the $\mathrm{Ca}^{2+}$ signal [6]. The transduction of changes in $\mathrm{Ca}^{2+}$ concentration requires $\mathrm{Ca}^{2+}$-binding proteins and these can contribute to the overall specificity of $\mathrm{Ca}^{2+}$ signalling. One well-characterised $\mathrm{Ca}^{2+}$-binding protein with neuronal functions is the ubiquitous protein calmodulin which binds $\mathrm{Ca}^{2+}$ through its four EF-hand domains [7]. Other EF-hand containing proteins have been found to be expressed in neurons and these contribute to the diversity of the neuronal $\mathrm{Ca}^{2+}$ signalling repertoire. These include two families known as the CaBPs/calneurons [8-13] and the neuronal calcium sensor (NCS)

\footnotetext{
* Correspondence: burgoyne@liv.ac.uk
Department of Cellular and Molecular Physiology, The Physiological

* Correspondence: burgoyne@liv.ac.uk
Department of Cellular and Molecular Physiology, The Physiological Laboratory, Institute of Translational Medicine, University of Liverpool, Liverpool, L69 3BX, UK
}

family. The latter family are the subject of this review. The NCS proteins have a wide range of physiological functions in neurons and in the photoreceptor cells in the retina. An emerging area is the recognition of the importance of NCS protein signalling in neuronal disease [14-20].

A key issue regarding the NCS proteins is how they can differentially affect specific aspects of neuronal function. NCS protein function is established by several factors determined by their intrinsic properties including their ability to interact with and regulate different target proteins. Several reviews on the NCS proteins have been published [21-25] and here we will concentrate on recent advances in the understanding of their physiological roles and the underlying target protein interactions that determine their specific functions.

\section{Overview of the NCS protein family}

The NCS proteins are encoded by 14 conserved genes in mammals and their diversity is increased by the existence of splice variants that are likely to modify their functions in ways yet to be fully determined $[21,23]$. The NCS family consists of NCS-1, hippocalcin, neurocalcin- $\delta$, VILIP1-3, recoverin, GCAP1-3 and KChIP1-4. The core EF-hand containing regions of these proteins are similar but they are largely distinguished by variable $\mathrm{N}$-terminal and $\mathrm{C}$-terminal domains. Genetic studies in various organisms have shown that loss of one of the NCS proteins can result in a distinct, detectable phenotype suggesting that they do not overlap in function 
sufficiently for the loss to be compensated by another family member or by calmodulin which can regulate some of the same targets [23]. Recoverin and the GCAPs have well-defined roles in the regulation of phototransduction and are only expressed in the retina $[26,27]$. The lack of redundancy of the other NCS proteins could come from restricted expression in particular classes of neurons but this is likely to be only a part of the explanation as many neurons appear to express multiple NCS proteins. Other factors that contribute to their non-redundancy include a higher $\mathrm{Ca}^{2+}$ sensitivity than calmodulin suggesting that they respond to different $\mathrm{Ca}^{2+}$ signals. They have varied subcellular locations through the post-translational modifications of myristoylation [28,29] or palmitoylation [30] that allow constitutive or alternatively $\mathrm{Ca}^{2+}$-dependent membrane association. In addition, they have specific binding targets for regulation.

\section{Physiological functions of the NCS proteins Recoverin}

As indicated above, recoverin has a characterised function in the retina [31] and indeed is only known to be expressed in photoreceptors, retinal cone bipolar cells and the pineal gland [32]. Recoverin's physiological role was suggested to be to regulate light sensitivity $[31,33]$. It does this through the direct inhibition of the retinal rhodopsin kinase in a $\mathrm{Ca}^{2+}$-dependent manner $[32,34,35]$. The normal phosphorylation of rhodopsin is crucial for the switch-off of the light response in photoreceptors [36]. A physiological role for recoverin in the regulation of light sensitivity has been established through study of mice where recoverin expression is reduced or knocked-out $[31,33]$. Rhodopsin kinase is recoverin's main known target [35,37] although it has also been found exert an additional, less characterized, effect on light sensitivity apparently independently of the kinase [38]. In addition it has been shown to be able to recruit the $\mathrm{Ca}^{2+}$-binding protein caldendrin to membranes [39]. Recoverin was the first of the NCS proteins to be discovered [40] and has since been extensively characterised from a biochemical perspective. The precise molecular basis for the inhibition of rhodopsin kinase [37] has been established through structural analyses (see below).

\section{GCAPs}

The GCAPs $[27,41]$ have role in light adaptation $[42,43]$ by activating or inhibiting retinal guanylyl cyclases $[44,45]$ at low or high $\mathrm{Ca}^{2+}$ concentration respectively [46]. The importance of the GCAPs is illustrated by the fact that various mutations in GCAP1 in humans result in cone dystrophies with photoreceptor degeneration [47]. The physiological importance of the GCAPs in the retina has also been established through knock-out of GCAP1 and GCAP2 in mice [42,48-50]. One key issue is why multiple GCAPs are required for light adaption. For example, GCAPs 1 and 2 are expressed in the same photoreceptor cells. Expression of GCAP2 in mice lacking GCAP1 and 2 did not result in full recovery of function indicating non-redundancy of function [50]. The existence of multiple GCAPs appears to be related to a need for sensors with differing $\mathrm{Ca}^{2+}$ sensitivities to allow responses to occur over a wide range of $\mathrm{Ca}^{2+}$ concentrations [27,51]. The structures of GCAP1 1, 2 and 3 have been characterised [52-55] but the molecular details of how they regulate guanylyl cyclases are yet to be determined.

\section{NCS-1}

The other NCS proteins have been implicated in a wide range of physiological functions in neuronal cells [23]. NCS-1 has been studied in various different organisms as it is expressed from yeast to man. This has resulted in it being implicated in many functional roles ranging from regulation of neuronal ion channels, membrane traffic, learning, neuronal growth and survival [23,25]. These functions appear to involve interaction of NCS-1 with multiple target proteins [17,56-59] many of which are apparently specific for this member of the family (Figure 1). Recent physiological studies have characterised several new roles for NCS-1 working through different pathways. Earlier work had suggested a role for NCS-1 in regulation of neurotransmitter release [60-62], voltage-gated $\mathrm{Ca}^{2+}$ channels $[63,64]$ and in short-term synaptic plasticity [65]. More recently NCS-1 has been shown to act in a pathway, involving interactions with another $\mathrm{Ca}^{2+}$ sensor PICK1, that mediates long-term depression (LTD) in rat cortical neurons [66]. In the mouse, NCS-1 has been implicated in exploratory behaviour and in the acquisition of spatial memory by regulating the surface expression of dopamine D2 receptors in the hippocampal dentate gyrus [67]. A study in Drosophila has shown that the fly NCS-1 orthologue frequenin which regulates both neurotransmitter release [60] and nerve terminal growth [68] does so through an interaction (revealed genetically) with the voltage-gated $\mathrm{Ca}^{2+}$ channel cacophony [69]. This channel is the fly equivalent of the mammalian P/Q-like Cav2.1 channel which is also regulated by calmodulin [70] and the other $\mathrm{Ca}^{2+}$-binding proteins VILIP-2 [71] and CaBP1 [72]. Overexpression of NCS-1 was demonstrated to induce neurite sprouting and spinal cord regeneration [73]. This appeared to involve activation of the PI3K/Akt pathway but it is not known whether NCS-1 directly interacts with proteins of this pathway. Finally, recent work has suggested that NCS-1 has a positive role in increasing $\mathrm{Ca}^{2+}$ signalling in cardiac cells through its 


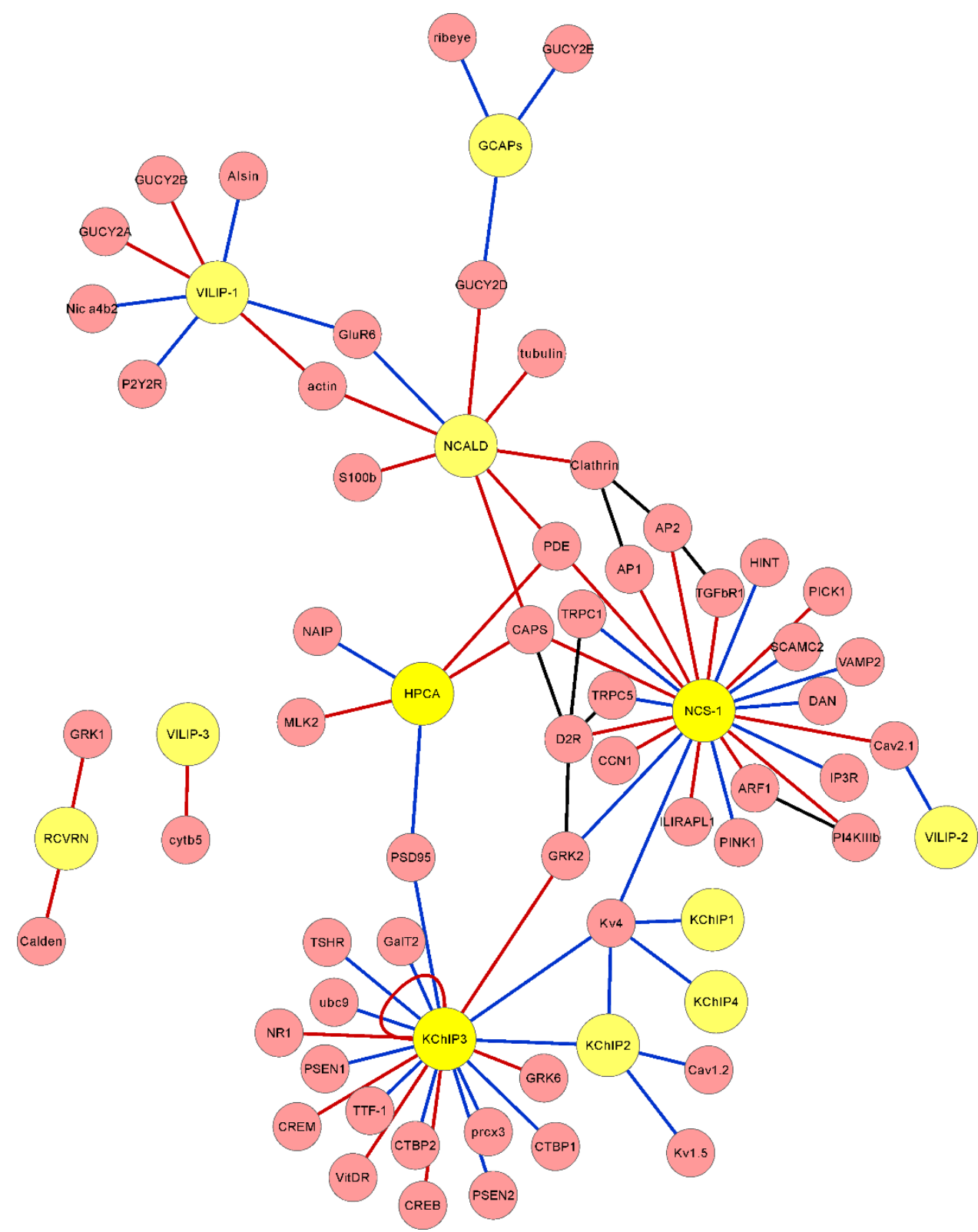

Figure 1 An interaction map of the known binding partners of the NCS proteins. The NCS protein family members are shown in yellow and binding partners in red with interactions directly with NCS proteins or between binding partners indicated. The edge colours indicate whether the interaction are with the $\mathrm{Ca}^{2+}$-bound form (red) or the apo form (blue) or if this is not applicable (black). The binding partners and their abbreviations are as follows: Actin, Alsin, AP1 (clathrin adaptor), AP2 (clathrin adaptor), ARF1 (ADP-ribosylation factor-1), Calden (Caldendrin), CAPS $\left(\mathrm{Ca}^{2+}\right.$-dependent activator protein for secretion), Cav1.2 ( $\mathrm{Ca}^{2+}$ channel), Cav2.1 ( $\mathrm{Ca}^{2+}$ channel), CALN (Calcineurin), Clathrin (Clathrin heavy chain), CREB (CAMP responsive element binding protein), CREM, (CAMP response element modulator), CTBP1/2 (C-terminal binding protein 1), cytb5 (cytochrome b5), D2R (dopamine D2 receptor), DAN (differential screening-selective gene aberrant in neuroblastome), GalT2 (galactosyl transferase 2), GluR6 (glutamate receptor 6), GRK1/2/6 (G protein-dependent receptor kinase 1/2/6), GUCY2A/2B/2D/2E (guanylate cyclase 2A/2B/2D/2E), HINT (histidine triad protein), ILIRAPL1 (interleukin receptor accessory protein like-1), IP3R (inositol 1, 4, 5 trisphosphate receptor), Kv1.5 (potassium channel), Kv4 (potassium channel), MLK2 (Mixed lineage kinase 2), NAIP (Neuronal apoptosis inhibitory protein), Nic a4b2 (nicotinic receptor containing $4 \alpha$ and $2 \beta$ subunits), NR1 (NMDA receptor type 1), P2Y2R (purinergic receptor type 2Y2R), PDE (phosphodiesterase 1A), PI4KIIllb (phosphatidylinositol-4-kinase III $\beta$ ), PICK1 (Protein interacting with C kinase 1), PINK1 (PTEN-induced kinase), prdx3 (Peroxiredoxin 3), PSD95 (postsynaptic density protein 95), PSEN1/2 (presenilin 1/2), ribeye (synaptic ribbon protein), S100b (S100 protein beta), SCAMC2 (Short calcium binding mitochondrial carrier 2), TGFbR1 (transforming growth factor $\beta$ receptor type 1), TRPC1/5 (transient receptor potential channel 1/5), TSHR (thyroid stimulating hormone receptor), TTF-1 (Thyroid transcription factor 1), tubulin ( $\alpha$ and $\beta$ tubulin), ubc9 (Ubiquitin conjugating enzyme 9), VAMP2 (vesicle -associated membrane protein 2), VitDR (vitamin D receptor). Note that for simplicity we have used the name KChIP3 despite the fact that several of the original descriptions of the interactions used the alternative terminology of DREAM or calsenilin (see main text). 
interaction with the IP3 receptor [74,75]. It is not clear, however, whether NCS-1 has a physiological role in regulating IP3 receptors in neurons.

\section{Hippocalcin and VILIPs}

Hippocalcin is expressed at highest levels in hippocampal neurons [76,77] and hippocalcin-deficient mice show an impairment in memory formation [78]. Hippocalcin has been suggested to be involved in LTD in hippocampal neurons by regulating endocytosis of the GluR2 class of AMPA glutamate receptors based on a direct interaction with the endocytotic clathrin adaptor AP2 [79]. More recently it has been shown to act via AP2 and the post-synaptic protein PSD-95 in a pathway for LTD triggered by muscarinic receptor activation [80]. Hippocalcin has also been suggested to regulate neuronal function as the calcium sensor for the potassium channels that lead to hyperpolarisation known as the slow after-hyperpolarisation currents (sAHP) [81,82]. The closely related NCS protein neurocalcin $\delta$ also regulates the sAHP [82]. Hippocalcin has a myristoyl switch that allows its reversible membrane association on $\mathrm{Ca}^{2+}$ binding [83]. This switch can be activated by $\mathrm{Ca}^{2+}$ influx through synaptic NMDA receptors to result in rapid translocation of hippocalcin into dendritic spines [84]. This translocation of hippocalcin may be important for LTD or the activation of SAHP. The VILIPs that are also closely related to hippocalcin may have other physiological roles [24] through regulation of voltage-gated $\mathrm{Ca}^{2+}$ channels [71], nicotinic acetylcholine receptors $[85,86]$ or purinergic P2X2 receptors [87]. Recent structural analyses suggest that VILIP-1 may function as a dimer $[88,89]$. VILIP-2 regulates the function of Cav2.1 calcium channels that are also regulated by calmodulin. Calmodulin binding to the $\alpha$-subunit of these channels is required for both $\mathrm{Ca}^{2+}$-dependent facilitation and inactivation of the channels [90,91]. In contrast, VILIP-2 increases facilitation but slows inactivation of the channels [71]. Recent work [92] has used calmodulin/VILIP2 chimeric proteins and has determined which domains in VILIP-2 are responsible for the differing effects of VILIP-2 compared to calmodulin. Distinct contributions of the $\mathrm{N}$ and $\mathrm{C}$-terminal regions of VILIP-2 to the regulation of the channels were identified.

\section{KChIPs/DREAM/calsenilin}

The KChIP proteins were so named based on their ability to interact with the $\mathrm{Kv} 4$ family of A-type rapidlyinactivating potassium channels [93]. One of the KChIIPs, KChIP3 was originally discovered in 1998 as a protein that bound to the presenilin proteins and was named calsenilin [94]. The characterisation of a protein that affects gene transcription through binding to a specific regulatory DNA motif (the downstream regulatory element or DRE) led to the identification of a human protein that was named downstream regulatory element antagonist modulator (DREAM) [95]. In the initial publication this protein appeared to have an alternative start codon giving a novel 30 residue extension at the $\mathrm{N}$-terminus. This sequence was subsequently corrected in the databases and it is clear that calsenilin, DREAM and KChIP3 proteins are in fact identical. The continued use of all three names is potentially confusing and so here we will refer to the protein as KChIP3. This is for simplicity and also since KChIP3 is closely related to KChIPs 1, 2 and 4 forming the KChIP sub-family of the NCS proteins.

In addition to the four KChIPs originally identified that are coded by 4 distinct genes there are multiple splice isoforms expressed [96]. The majority of the KChIP isoforms that have been examined regulate the gating properties of Kv4 channels [93] and also stimulate their traffic through the secretory pathway to the cell surface [93,97-99]. In contrast, certain isoforms of KChIPs 2, 3 and 4 inhibit Kv4 channel traffic to the plasma membrane due to the existence of an alternative N-terminal inhibitory domain (the KIS domain) [100]. This hydrophobic sequence has been suggested to be a trans-membrane domain [101] but structural characterisation has shown that the N-terminal helix of KChIP4a instead binds within the hydrophobic pocket of KChIP4a to displace the N-terminus of Kv4 [102,103] explaining its dominant inhibitory effect on Kv4 channel traffic.

Recent work has suggested that KChIPs may also play a role in the regulation of voltage -gated $\mathrm{Ca}^{2+}$ channel signalling. T-type (Cav3) $\mathrm{Ca}^{2+}$ channels were found to be present in a signalling complex containing Kv4 channels and $\mathrm{Ca}^{2+}$ entry though the Cav3 channels modified the gating of the $\mathrm{Kv} 4$ potassium channels. This effect was mediated by KChIP3 as the $\mathrm{Ca}^{2+}$ sensor and interestingly this could not be replaced by KChIPs 1,2 or 4 providing further evidence for specific actions of the different KChIPs [104]. In addition, to this study, it has also been recently suggested that KChIP2 is a directly interacting regulator of L-type (Cav1, 2) $\mathrm{Ca}^{2+}$ channels and that KChIP2 can increase channel density without an effect on channel traffic [105].

The multiple possible roles of KChIP3/calsenilin/ DREAM that gave rise to the independent identifications have been supported by studies in KChIP3 knock-out mice $[106,107]$ It is clear that KChIP3 regulates expression of multiple genes in addition to its other cellular roles [108]. The gene regulatory function (DREAM) involves in part its direct interaction with the DNA DRE motif but growing evidence has shown its interaction with several co-repressor proteins involved in gene regulation [109-111]. 
The interaction of KChIP3 (calsenilin) with the presenilins [94] has been of interest given the importance of mutations in the presenilins in familial forms of Alzheimer's disease [112]. The full significance and the physiological relevance of the interaction of KChIP3 with the presenilins remains to be established, however, although both earlier [113] and more recent work has suggested an important role in $\mathrm{Ca}^{2+}$ signalling [114]. In addition, it has been suggested that the interaction of KChIP3/calsenilin could regulate the processing function of preseni$\operatorname{lin} / \gamma$-secretase $[115,116]$.

Further analysis of transgenic mice has identified additional physiological neuronal roles for KChIP3. From two independent studies on the knock-out mouse there is evidence for an enhancement of learning (contextual fear memory) in the absence of KChIP3 $[117,118]$. One study found an increase in long-term potentiation (LTP) in the hippocampus of the knock-out mice [117]. In a study of mice expressing a $\mathrm{Ca}^{2+}$-insensitive active mutant form of DREAM learning was impaired consistent with the knock-out mouse studies. In contrast to the knock-out mouse data however no effect on LTP was observed but instead LTD was reduced [119]. The effect of DREAM on LTD was suggested to be due to an interaction with the post-synaptic protein PSD-95 that could affect NMDA receptor function [119]. Another study has identified a direct interaction of KChIP3 with the NR1 subunit of the NMDA receptor [120]. This interaction inhibits the surface expression of NMDA receptors and could contribute to its inhibitory effect on learning and memory. Another important role for KChIP3 in neuronal physiology has come from other studies of the mice expressing the $\mathrm{Ca}^{2+}$-insensitive constitutively active mutant. This work has identified a requirement for KChIP3 in central nervous system mechanisms of pain sensation and this involved the action of BDNF (brain-derived neurotrophic factor) [121].

A role for KChIP1 in synaptic plasticity and behaviour has also been revealed from the study of a mouse KChIP1 knock-out. KChIP1 was found to be expressed at high levels in GABAergic interneurons [122]. In the absence of KChIP1, abnormalities in GABAergic neurotransmission and an increase in anxiety-related behaviours was identified [123]. In contrast to the positive role of KChIP1 in stimulating traffic of Kv4 channels, the KChIP1 knock-out study found an increase in potassium channel density which could be related to an inhibitory effect of KChIPs that has been observed for traffic of Kv1.5 potassium channels to the plasma membrane [124].

Apart from the distinct effects of some KChIP isoforms on $\mathrm{Kv} 4$ channel traffic noted above there is relatively little information on why there are so many of them (potentially at least 16 isoforms [96]). One study detected a specific effect of over-expressed KChIP3 compared to single isoforms of KChIP1, 2 and 4 on $\mathrm{Ca}^{2}$ + signalling and neurotransmitter exocytosis [98]. There is evidence that different classes of neurons express different subsets of KChIP proteins [125,126]. One recent study showed that KChIPs 2, 3 and 4 can all contribute to Kv4 channel function in the same mouse cortical pyramidal neurons [127]. In contrast, another study found that Kv4 potassium currents in hippocampal interneurons were largely dependent on only KChIP1 [128]. Another possible clue explaining the reason for multiple KChIPs may the existence of differing neuronal signalling complexes involving Kv4 channels and KChIPs $[104,129]$. It is unclear whether the KChIP isoforms have specific functions due to interaction with distinct target proteins. An increasingly large number of targets are being identified for KChIP3 [130] but less is known about the targets of the other KChIPs (Figure 1).

\section{Structural insights into NCS protein function and target specificity}

The structures of a number of NCS protein family members have been solved by the use of X-ray crystallography or NMR spectroscopy. These variously include structures of apo and $\mathrm{Ca}^{2+}$-bound forms with or without N-terminal myristoylation [131]. While the NCS proteins have similar overall molecular structures there are differences that provide clues to their specificity of function and more specifically their target protein interactions. They all possess four EF-hand domains but in each case EF hand 1 is inactive in binding divalent cations. The $\mathrm{Ca}^{2+}$-bound forms of the NCS proteins either have 3 bound $\mathrm{Ca}^{2+}$ ions or in the case of recoverin [132], KChIP1 [133,134] and KChIP3 [135] have 2 bound $\mathrm{Ca}^{2+}$ ions and these proteins differ in which EF hands are active. Many but not all of the NCS proteins are N-terminally myristoylated to allow membrane association and the use of the myristoylation confers different properties [136,131]. The structurally most extensively characterised NCS protein is recoverin. This protein has a well defined $\mathrm{Ca}^{2+} /$ myristoyl switch mechanism in which the myristoyl group is sequestered in the $\mathrm{Ca}^{2+}$ free state and is flipped out on $\mathrm{Ca}^{2+}$ binding to allow membrane association [132,137]. A dynamic $\mathrm{Ca}^{2+} /$ myristoyl switch mechanism allowing reversible membrane association has been demonstrated in live cell studies for hippocalcin $[28,83,84]$ and the VILIPs $[138,139]$. In contrast, NCS-1 appears to have a solvent exposed myristoyl group that drives its constitutive membrane association $[28,29]$ although it does dynamically cycle between the membrane and cytosol [18]. A further important aspect of the myristoyl group is that it is not sequestered identically in all characterised 
structures $[53,132,140]$ and can affect the overall protein structure and stability [55,141]. An additional aspect of the NCS proteins that may be crucial for the specificity of target interactions is that they have a very variable distribution of charged residues particularly on their Cterminal halves [131].

Insight into the molecular basis of NCS protein specificity has come from structural characterisation of NCS/ target complexes (Figure 2). The structures have been solved for the complex of recoverin with a rhodopsin kinase fragment [37], the frequenin/Pik1 complex from Saccharomyces cerevisiae and Schizosaccharomyces pombe $[140,142]$ and a complex of KChIP1 with the Nterminus of the Kv4.3 channel $[143,144]$. Additional information has also come from the structure of KChIP4a, the role of which is to inhibit fast inactivation of the Kv4 channel and to reduce its traffic to the plasma membrane through its specific $\mathrm{K}^{+}$channel inactivation suppressor (KIS) domain [100,97]. This structure showed [102] that the N-terminal KIS domain is sequestered in the hydrophobic groove that in KChIP1 is involved in interaction with the Kv4 channel and can thereby compete off this interaction $[143,144]$. The consequence is that unlike KChIP1, KChIP4a would only be able to interact with $\mathrm{Kv} 4$ through the additional site 2 interaction identified for KChIP1/Kv4.3 [143,144]. In addition, a model has been generated for the interaction of NCS-1 with dopamine D2/D3 receptors [145]. NCS-1 regulates the internalisation of D2 and D3 receptors through interaction with the short cytoplasmic C-terminus of the receptor [59]. A synthetic peptide based on this sequence directly binds to NCS-1 $[145,146]$ allowing characterisation of the interaction by use of NMR. The key features that have emerged from these studies are the importance of an exposed hydrophobic groove lined by conserved hydrophobic residues for binding $\alpha$-helical regions of the target protein, the importance of nonconserved residues in specific target contacts and the differential role of the NCS protein C-terminus in target interactions.

All of the characterised interactions shown in Figure 2 involve $\alpha$-helix binding within a hydrophobic groove in the N-terminal half of the NCS protein. In the case of frequenin [140,142] and predicted for NCS-1 [145], two $\alpha$-helices are able to bind to separate hydrophobic pockets in a much longer exposed cleft. The exposure of the C-terminal part of the groove would require significant movement of the $\mathrm{C}$-terminal $\alpha$-helix of the NCS protein $[142,145]$. In a recent paper is has been proposed that the C-terminus of NCS-1 binds directly to the hydrophobic groove as a mimic of the target ligand to stabilise the structure of NCS-1 [147]. A movement of the C-terminal H10 helix of KChIP1 was observed in the KV4.3 bound structure [143,144] compared to the
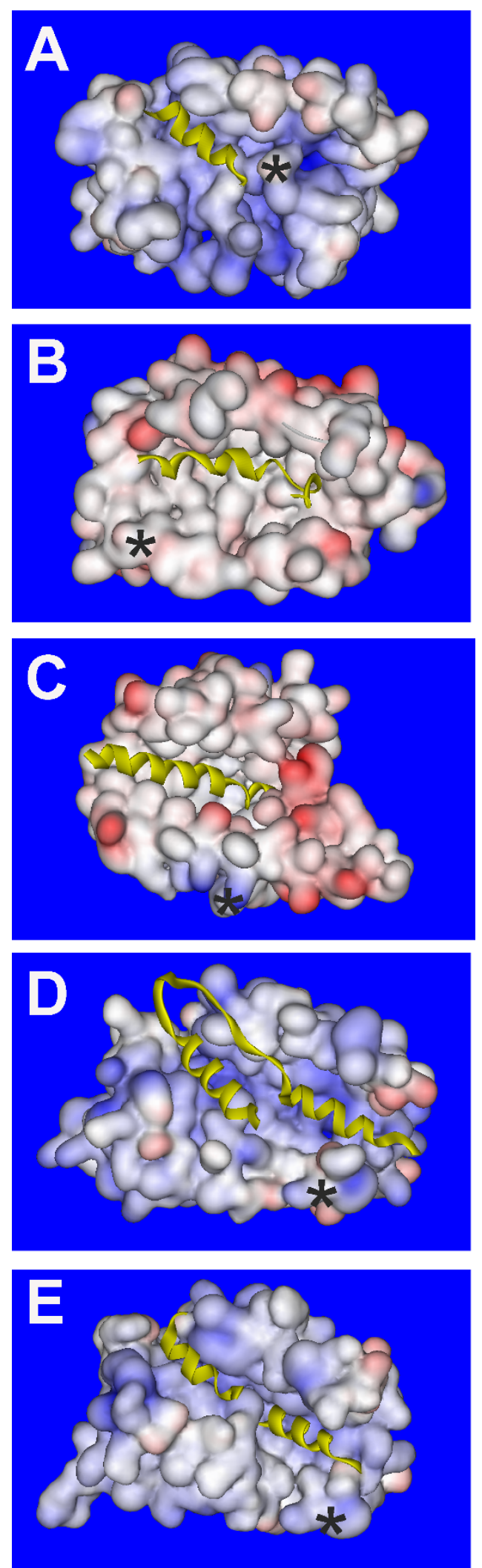

Figure 2 Structures of NCS proteins showing interactions within the exposed hydrophobic groove. (A) Structure of $\mathrm{Ca}^{2}$ 
${ }^{+}$-bound bovine recoverin with bound $\mathrm{N}$-terminal fragment of rhodopsin kinase including residues 1-25 ([37]; PDB, 2194). Recoverin is shown in space-filling representation and the rhodopsin kinase is shown in yellow. The rhodopsin kinase fragment forms an $\alpha$-helix that is embedded in an N-terminal hydrophobic pocket of recoverin. The asterisk indicates the position of the C-terminus of recoverin. (B) Structure of $\mathrm{Ca}^{2+}$-bound human KChIP1 showing the binding of the N-terminal residues 3-27 of Kv4.3 ([143,144]; PDB, $2 \mid 2 \mathrm{~N})$. KChIP1 is shown in space-filling representation and the Kv4.3 fragment which forms an $\alpha$-helix shown in yellow is embedded in a hydrophobic groove running across KChIP1. An additional interaction site of Kv4.3 with helix H2 of KChIP1 is omitted for clarity. The asterisk indicates the position of the C-terminus of KChIP1. (C) Structure of of $\mathrm{Ca}^{2+}$-bound mouse KChIP4a ([102];PDB, 3DD4) with the structure shown in space-filling representation apart from the N-terminal residues 1-23 which are shown in yellow. The $\mathrm{N}$-terminus forms an $\alpha$-helix which is embedded within the $\mathrm{N}$ terminal part of the exposed hydrophobic groove of KChIP4a. The asterisk indicates the position of the C-terminus of KChIP4a. (D) Structure of of $\mathrm{Ca}^{2+}$-bound S. cerevisiae Frq1 with bound Pik1(121175) ([142];PDB, 2JU0) the structure of Frq1 is shown in space-filling representation and the Pik1 fragment in yellow. Pik1 forms two $\alpha$ helices joined by a loop and the helices are bound to the $\mathrm{N}$ - and C-terminal parts of a large hydrophobic groove running across Frq1. The asterisk indicates the position of the C-terminus of Frq1. (E) Model for the structure of of $\mathrm{Ca}^{2+}$-bound human NCS-1 with two bound molecules of the C-terminal peptide of the D2/D3 receptor. The structure of NCS-1 derived from PDB 1G81[149] is shown in space-filling representation and the D2/D3 peptides in yellow. The two peptides are bound to the $\mathrm{N}$ - and C-terminal parts of the large hydrophobic groove running across Frq1. The asterisk indicates the position of the C-terminus of NCS-1.

unbound form of KChIP1 [134] that would allow the single $\alpha$-helix of Kv4.3 to interact with hydrophobic residues more $\mathrm{C}$-terminal than is the case for the recoverin/rhodopsin kinase complex. (Note that Kv4.3 also makes a second contact with the H2 helix of KChIP1 that is not shown in Figure 2[143,144]). In the recoverin/rhodopsin kinase complex the C-terminal helix of recoverin occludes the hydrophobic cleft and indeed residues in the $\mathrm{C}$-terminus are crucial for the interaction with the target [148]. From the structures available it is possible to see how a similar mechanism for target interaction through binding of a target $\alpha$-helix into an exposed hydrophobic cleft has been modified in each protein to generate high specificity for target binding.

\section{Conclusions and Future Directions}

There is an increasing understanding of the importance and diverse functional roles of the NCS proteins in transducing neuronal $\mathrm{Ca}^{2+}$ signals. It is clear that additional roles will continue to emerge. Additional analysis of the protein targets for the NCS proteins and the structural characterisation of these interactions will allow us to further understand the molecular basis for the specificity of the NCS protein function. In addition, further study will be required to fully define the importance of NCS protein signalling, or disorders in this signalling, in neuronal disease.

\section{Acknowledgements}

Work in the authors' laboratory is supported by grants from the Wellcome Trust.

\section{Authors' contributions}

RDB drafted the manuscript. RDB and LPH revised the manuscript. RDB and $\mathrm{LPH}$ read and approved the final manuscript.

\section{Competing interests}

The authors declare that they have no competing interests.

Received: 6 December 2011 Accepted: 23 January 2012

Published: 23 January 2012

\section{References}

1. Barclay JW, Morgan A, Burgoyne RD: Calcium-dependent regulation of exocytosis. Cell Calcium 2005, 38:343-353.

2. Burgoyne RD, Morgan A: Secretory granule exocytosis. Physiol Rev 2003, 83:581-632.

3. Augustine GJ, Santamaria F, Tanaka K: Local calcium signaling in neurons. Neuron 2003, 40:331-346.

4. Fernandez-Chacon R, Konigstorfer A, Gerber SH, Garcia J, Matos MF, Stevens CF, Brose N, Rizo J, Rosenmund C, Sudhof TC: Synaptotagmin I functions as a calcium regulator of release probability. Nature 2001, 410:41-49.

5. Berridge MJ: Neuronal calcium signalling. Neuron 1998, 21:13-26.

6. Berridge MJ, Lipp P, Bootman MD: The versatility and universality of calcium signalling. Nature Rev Mol Cell Biol 2000, 1:11-21.

7. Faas GC, Raghavachari S, Lisman JE, Mody I: Calmodulin as a direct detector of $\mathrm{Ca}^{2+}$ signals. Nat Neurosci 2011, 14(3):301-304.

8. McCue HV, Haynes LP, Burgoyne RD: Bioinformatic analysis of CaBP/ calneuron proteins reveals a family of highly conserved vertebrate $\mathrm{Ca}^{2+}$ binding proteins. BMC Res Notes 2010, 3(1):118

9. McCue HV, Haynes LP, Burgoyne RD: The Diversity of Calcium Sensor Proteins in the Regulation of Neuronal Function. Cold Spring Harb Perspect Biol 2010, a004085.

10. Mikhaylova M, Sharma Y, Reissner C, Nagel F, Aravind P, Rajini B, Smalla KH, Gundelfinger ED, Kreutz MR: Neuronal $\mathrm{Ca}^{2+}$ signaling via caldendrin and calneurons. Biochim Biophys Acta 2006, 1763:1229-1237.

11. Haeseleer F, Sokal I, Verlinde CLMJ, Erdjument-Bromage H, Tempst $P$, Pronin AN, Benovic JL, Fariss RN, Palczewski K: Five members of a novel $\mathrm{Ca}^{2+}$ binding protein (CABP) subfamily with similarity to calmodulin. $J$ Biol Chem 2000, 275:1247-1260.

12. Mikhaylova M, Reddy PP, Kreutz MR: Role of neuronal $\mathrm{Ca}^{2+}$-sensor proteins in Golgi-cell-surface membrane traffic. Biochem Soc Trans 2010, 38(Pt 1):177-180

13. Haynes LP, Tepikin AV, Burgoyne RD: Calcium Binding Protein 1 is an inhibitor of agonist-evoked, inositol 1, 4, 5-trisphophate-mediated calcium signalling. J BiolChem 2004, 279:547-555.

14. Braunewell K-H, Riederer P, Spilker C, Gundelfinger ED, Bogerts B, Bernstein $\mathrm{H}$-G: Abnormal localisation of two neuronal calcium sensor proteins, visinin-like proteins (VILIPs)- 1 and -3 , in neocortical brain areas of alzheimer disease patients. Dement Gariatr Cogn Disord 2001, 12:110-116.

15. Braunewell $\mathrm{K}-\mathrm{H}$ : The darker side of $\mathrm{Ca}^{2+}$ signaling by neuronal $\mathrm{Ca}^{2}$ ${ }^{+}$-sensor proteins: from Alzheimer's disease to cancer. Trends Pharmacol Sci 2005, 26:345-351.

16. Seaton G, Hogg EL, Jo J, Whitcomb DJ, Cho K: Sensing change: the emerging role of calcium sensors in neuronal disease. Semin Cell Dev Biol 2011, 22(5):530-535.

17. Bahi N, Friocourt G, Carrié A, Graham ME, Weiss JL, Chafey P, Fauchereau F, Burgoyne RD, Chelly J: IL1 receptor accessory protein like, a protein involved in X-linked mental retardation, interacts with Neuronal Calcium Sensor-1 and regulates exocytosis. Human Mol Genetics 2003, 12:1415-1425. 
18. Handley MT, Lian LY, Haynes LP, Burgoyne RD: Structural and functional deficits in a neuronal calcium sensor- 1 mutant identified in a case of autistic spectrum disorder. PLOS ONE 2010, 5(5):e10534.

19. Piton A, Michaud JL, Peng H, Aradhya S, Gauthier J, Mottron L, Champagne N, Lafreniere RG, Hamdan FF, Joober R, et al: Mutations in the calcium-related gene IL1RAPL1 are associated with autism. Hum Mol Genet 2008, 17(24):3965-3974

20. Kitiratschky VB, Behnen P, Kellner U, Heckenlively JR, Zrenner E, Jagle $H$, Kohl S, Wissinger B, Koch KW: dystrophies impair calcium-mediated regulation of guanylate cyclase. Hum Mutat 2009, 8:E782-796.

21. Burgoyne RD, Weiss $J$ : The neuronal calcium sensor family of $\mathrm{Ca}^{2}$ +-binding proteins. Biochem J 2001, 353:1-12.

22. Burgoyne RD, O'Callaghan DW, Hasdemir B, Haynes LP, Tepikin AV: Neuronal calcium sensor proteins: multitalented regulators of neuronal function. Trends Neurosci 2004, 27:203-209.

23. Burgoyne RD: Neuronal calcium sensor proteins: generating diversity in neuronal $\mathrm{Ca}^{2+}$ signalling. Nat Rev Neurosci 2007, 8(3):182-193.

24. Braunewell KH, Klein-Szanto AJ: Visinin-like proteins (VSNLs): interaction partners and emerging functions in signal transduction of a subfamily of neuronal $\mathrm{Ca}^{2+}$-sensor proteins. Cell Tissue Res 2009, 335(2):301-316.

25. Weiss $\lrcorner$, Hui $H$, Burgoyne RD: Neuronal calcium sensor-1 regulation of calcium channels, secretion, and neuronal outgrowth. Cell Mol Neurobio 2010, 30(8):1283-1292

26. Polans A, Baehr W, Palczewski K: Turned on by Ca2+! The physiology and pathology of Ca2+-binding proteins in the retina. Trends in Neurosciences 1996, 19(12):547-554

27. Koch K-W: GCAPs, the classical neuronal calcium sensors in the retina. A $\mathrm{Ca}^{2+}$ - relay model of guanylate cyclase activation. Calcium Binding Proteins 2006, 1(1):3-6.

28. O'Callaghan DW, Ivings L, Weiss $J$, Ashby MC, Tepikin AV, Burgoyne RD: Differential use of myristoyl groups on neuronal calcium sensor proteins as a determinant of spatio-temporal aspects of $\mathrm{Ca}^{2+}$-signal transduction. J BiolChem 2002, 277:14227-14237.

29. O'Callaghan DW, Hasdemir B, Leighton M, Burgoyne RD: Residues within the myristoylation motif determine intracellular targeting of the neuronal $\mathrm{Ca}^{2+}$ sensor protein KChIP1 to post-ER transport vesicles and traffic of Kv4 K+ channels. J Cell Sci 2003, 116:4833-4845.

30. Takimoto $K$, Yang E-K, Conforti L: Palmitoylation of KChIP splicing variants is required for efficient cell surface expression of Kv4.3 channels. $J$ BiolChem 2002, 277:26904-26911.

31. Makino CL, Dodd RL, Chen J, Burns ME, Roca A, Simon MI, Baylor DA: Recoverin regulates light-dependent phosphodiesterase activity in retinal rods. J Gen Physiol 2004, 123:729-741.

32. Bazhin AV: Recoverin. Calcium Binding Proteins 2008, 3(1):e1-e3.

33. Chen CK, Woodruff ML, Chen FS, Chen D, Fain GL: Background light produces a recoverin-dependent modulation of activated-rhodopsin lifetime in mouse rods. J Neurosci 2010, 30(4):1213-1220.

34. Klenshin VA, Calvert PD, Bownds MD: Inhibition of rhodopsin kinase by recoverin. J Biol Chem 1995, 270:16147-16152

35. Komolov KE, Senin II, Kovaleva NA, Christoph MP, Churumova VA, Akhtar M, Grigoriev II, Philippov PP, Koch KW: Mechanism of rhodopsin kinase regulation by recoverin. J Neurochem 2009, 110(1):72-79.

36. Mendez A, Burns ME, Roca A, Lem J, Wu LW, Simon MI, Baylor DA, Chen J: Rapid and reproducible deactivation of rhodopsin requires multiple phosphorylation sites. Neuron 2000, 28(1):153-164.

37. Ames JB, Levay K, Wingard JN, Lusin JD, Slepak VZ: Structural Basis for Calcium-induced Inhibition of Rhodopsin Kinase by Recoverin. J Biol Chem 2006, 281(48):37237-37245.

38. Sampath A, Strissel KJ, Elias R, Arshavsky VY, McGinnis JF, Rieke F, Hurley JB: Recoverin improves rod-mediated vision by enhancing signal transmission in the mouse retina. Neuron 2005, 46:413-420.

39. Fries R, Reddy PP, Mikhaylova M, Haverkamp S, Wei T, Muller M, Kreutz MR Koch KW: Dynamic cellular translocation of caldendrin is facilitated by the Ca2+-myristoyl switch of recoverin. J Neurochem 2010, 113(5):1150-1162.

40. Dizhoor AM, Ray S, Kumar S, Niemi G, Spencer M, Brolley D, Walsh KA, Philipov PP, Hurley JB, Stryer L: Recoverin: a calcium sensitive activator of retinal rod guanylate cyclase. Science 1991, 251:915-918.

41. Palczewski K, Sokal I, Baehr W: Guanylate cyclase-activating proteins: structure, function and diversity. Biochem Biophys Res Comm 2004 322:1123-1130
42. Pennesi ME, Howes KA, Baehr W, Wu SM: Guanylate cyclase-activating protein (GCAP) 1 rescues cone recovery kinetics in GCAP1/GCAP2 knockout mice. Proc Natl Acad Sci USA 2003, 100:6783-6788.

43. Sakurai K, Chen J, Kefalov VJ: Role of guanylyl cyclase modulation in mouse cone phototransduction. J Neurosci 2011, 31(22):7991-8000.

44. Dizhoor AM, Olshevskaya EV, Henzel WJ, Wong SC, Stults JT, Ankoudinova I, Hurley JB: Cloning, Sequencing, and Expression of a 24-Kda Ca2 +-Binding Protein Activating Photoreceptor Guanylyl Cyclase. J Biol Chem 1995, 270(42):25200-25206

45. Gorczyca WA, Polans AS, Surgucheva IG, Subbaraya I, Baehr W, Palczewski K: Guanylyl cyclase-activating protein - a calcium-sensitive regulator of phototransduction. J Biol Chem 1995, 270(37):22029-22036

46. Dizhoor AM, Hurley JB: Inactivation of EF-hands makes GCAP-2 (p24) a constitutive activator of photoreceptor guanulyl cyclase by preventing a $\mathrm{Ca}^{2+}$-induced "activator-to-inhibitor" transition. J Biol Chem 1996, 271:19346-19350.

47. Behnen P, Dell'Orco D, Koch KW: Involvement of the calcium sensor GCAP1 in hereditary cone dystrophies. Biol Chem 2010, 391(6):631-637.

48. Howes KA, Pennesi ME, Sokal I, Church-Kopish J, Schmidt B, Margolis D, Frederick JM, Rieke F, Palczewski K, Wu SM, et al: GCAP1 rescues rod photoreceptor response in GCAP1/GCAP2 knockout mice. EMBO Journal 2002, 21(7):1545-1554.

49. Burns ME, Mendez A, Chen J, Baylor DA: Dynamics of cyclic AMP synthesis in retinal rods. Neuron 2002, 36:81-91

50. Mendez A, Burns ME, Sokal I, Dizhoor AM, Baehr W, Palczewski K, Baylor DA Chen J: Role of guanylate cyclase-activating proteins (GCAPs) in setting the flash sensitivity of rod photoreceptors. Proc Natl Acad Sci USA 2001, 98(17):9948-9953.

51. Scholten A, Koch KW: Differential calcium signaling by cone specific guanylate cyclase-activating proteins from the zebrafish retina. PLOS ONE 2011, 6(8):e23117.

52. Stephen R, Palczewski K, Sousa MC: The crystal structure of GCAP3 suggests molecular mechanism of GCAP-linked cone dystrophies. J Mol Biol 2006, 359(2):266-275.

53. Stephen R, Bereta G, Golczak M, Palczewski K, Sousa MC: Stabilizing function for myristoyl group revealed by the crystal structure of a neuronal calcium sensor, guanylate cyclase-activating protein 1. Structure 2007, 15(11):1392-1402.

54. Ames JB, Dizhoor AM, Ikura M, Palczewski K, Stryer L: Three-dimensional structure of guanylyl cyclase activating protein-2, a calcium-sensitive modulator of photoreceptor guanylyl cyclases. J Biol Chem 1999, 274:19329-19337.

55. Orban T, Bereta G, Miyagi M, Wang B, Chance MR, Sousa MC, Palczewski K Conformational changes in guanylate cyclase-activating protein 1 induced by $\mathrm{Ca}^{2+}$ and $\mathrm{N}$-terminal fatty acid acylation. Structure 2010, 18(1):116-126.

56. Haynes $L P$, Thomas $G M H$, Burgoyne RD: Interaction of neuronal calcium sensor-1 and ARF1 allows bidirectional control of phosphatidylinositol 4kinase beta and TGN-plasma membrane traffic. J Biol Chem 2005, 280:6047-6054.

57. Haynes LP, Fitzgerald DJ, Wareing B, O'Callaghan DW, Morgan A, Burgoyne RD: Analysis of the interacting partners of the neuronal calcium-binding proteins L-CaBP1, hippocalcin, NCS-1 and neurocalcin. Proteomics 2006, 6:1822-1832

58. Petko JA, Kabbani N, Frey C, Woll M, Hickey K, Craig M, Canfield VA, Levenson R: Proteomic and functional analysis of NCS-1 binding proteins reveals novel signaling pathways required for inner ear development in zebrafish. BMC neuroscience 2009, 10:27.

59. Kabbani N, Negyessy L, Lin R, Goldman-Rakic P, Levenson R: Interaction with the neuronal calcium sensor NCS-1 mediates desensitization of the D2 dopamine receptor. J Neurosci 2002, 22:8476-8486.

60. Pongs O, Lindemeier J, Zhu XR, Theil T, Endelkamp D, Krah-Jentgens I, Lambrecht H-G, Koch KW, Schwemer J, Rivosecchi R, et al: Frequenin - A novel calcium-binding protein that modulates synaptic efficacy in the drosophila nervous system. Neuron 1993, 11:15-28.

61. McFerran BW, Graham ME, Burgoyne RD: NCS-1, the mammalian homologue of frequenin is expressed in chromaffin and PC12 cells and regulates neurosecretion from dense-core granules. J Biol Chem 1998, 273:22768-22772.

62. McFerran BW, Weiss $J$ L, Burgoyne RD: Neuronal $\mathrm{Ca}^{2+}$-sensor 1 : Characterisation of the myristoylated protein, its cellular effects in 
permeabilised adrenal chromaffin cells, $\mathrm{Ca}^{2+}$-independent membraneassociation and interaction with binding proteins suggesting a role in rapid $\mathrm{Ca}^{2+}$ signal transduction. J Biol Chem 1999, 274:30258-30265.

63. Weiss $\mathrm{J}$, Archer DA, Burgoyne RD: NCS-1/frequenin functions in an autocrine pathway regulating $\mathrm{Ca}^{2+}$ channels in bovine adrenal chromaffin cells. J Biol Chem 2000, 275:40082-40087.

64. Tsujimoto T, Jeromin A, Satoh N, Roder JC, Takahashi T: Neuronal calcium sensor 1 and activity-dependent facilitation of P/Q-type calcium channel currents at presynaptic nerve terminals. Science 2002, 295:2276-2279.

65. Sippy T, Cruz-Martin A, Jeromin A, Schweizer FE: Acute changes in shortterm plasticity at synapses with elevated levels of neuronal calcium sensor-1. Nature Neurosci 2003, 6:1031-1038.

66. Jo J, Heon S, Kim MJ, Son GH, Park Y, Henley JM, Weiss JL, Sheng M, Collingridge GL, Cho K: Metabotropic glutamate receptor-mediated LTD involves two interacting $\mathrm{Ca}^{2+}$ sensors, NCS-1 and PICK1. Neuron 2008, 60(6):1095-1111.

67. Saab BJ, Georgiou J, Nath A, Lee FJ, Wang M, Michalon A, Liu F, Mansuy IM, Roder JC: NCS-1 in the dentate gyrus promotes exploration, synaptic plasticity, and rapid acquisition of spatial memory. Neuron 2009, 63(5):643-656.

68. Romero-Pozuelo J, Dason JS, Atwood HL, Ferrus A: Chronic and acute alterations in the functional levels of Frequenins 1 and 2 reveal their roles in synaptic transmission and axon terminal morphology. Eur $J$ Neurosci 2007, 26(9):2428-2443.

69. Dason JS, Romero-Pozuelo J, Marin L, lyengar BG, Klose MK, Ferrus A, Atwood HL: Frequenin/NCS-1 and the $\mathrm{Ca}^{2+}$-channel \{alpha\}1-subunit coregulate synaptic transmission and nerve-terminal growth. J Cell Sci 2009, 122:4109-4121

70. Lee A, Wong ST, Gallagher D, Li B, Storm DR, Scheuer T, Catterall WA: Ca ${ }^{2}$ +/calmodulin binds to and modulates P/Q type calcium channels. Nature 1999, 399:155-159.

71. Lautermilch NJ, Few AP, Scheuer T, Catterall WA: Modulation of Cav2.1 channels by the neuronal calcium-binding protein visinin-like protein-2. J Neurosci 2005, 25:7062-7070.

72. Lee A, Westenbroek RE, Haeseleer F, Palczewski K, Scheuer T, Catterall WA Differential modulation of Cav2.1 channels by calmodulin and $\mathrm{Ca}^{2}$ +-binding protein 1. Nature Neuroscience 2002, 5:210-217.

73. Yip PK, Wong LF, Sears TA, Yanez-Munoz RJ, McMahon SB: Cortical overexpression of neuronal calcium sensor-1 induces functional plasticity in spinal cord following unilateral pyramidal tract injury in rat. PLOS Biol 2010, 8(6):e1000399.

74. Nakamura TY, Jeromin A, Mikoshiba K, Wakabayashi S: Neuronal calcium sensor-1 promotes immature heart function and hypertrophy by enhancing $\mathrm{Ca}^{2+}$ signals. Circ Res 2011, 109(5):512-523.

75. Zhang K, Heidrich FM, DeGray B, Boehmerle W, Ehrlich BE: Paclitaxel accelerates spontaneous calcium oscillations in cardiomyocytes by interacting with NCS-1 and the InsP3R. J Mol Cell Cardiol 2010, 49(5):829-835

76. Kobayashi M, Takamatsu K, Saitoh S, Miura M, Noguchi T: Molecular cloning of hippocalcin, a novel calcium-binding protein of the recoverin family exclusively expressed in hippocampus. Biochem Biophys Res Commun 1992, 189:511-517.

77. Paterlini M, Revilla V, Grant AL, Wisden W: Expression of the neuronal calcium sensor protein family in the rat brain. Neurosci 2000, 99:205-216

78. Kobayashi M, Masaki T, Hori K, Masuo Y, Miyamoto M, Tsubokawa H, Noguchi H, Nomura M, Takamatsu K: Hippocalcin-deficient mice display a defect in CAMP response element-binding protein activation associated with impaired spatial and associative memory. Neurosci 2005, 133:471-484

79. Palmer CL, Lim W, Hastie PG, Toward M, Korolchuk VI, Burbidge SA, Banting G, Collingridge GL, Isaac JT, Henley JM: Hippocalcin functions as a calcium sensor in hippocampal LTD. Neuron 2005, 47(4):487-494.

80. Jo J, Son GH, Winters BL, Kim MJ, Whitcomb DJ, Dickinson BA, Lee YB, Futai K, Amici M, Sheng M, et al: Muscarinic receptors induce LTD of NMDAR EPSCs via a mechanism involving hippocalcin, AP2 and PSD-95. Nat Neurosci 2010, 13(10):1216-1224

81. Tzingounis AV, Kobayashi M, Takamatsu K, Nicoll RA: Hippocalcin gates the calcium activation of the slow afterhyperpolarization in hippocampal pyramidal cells. Neuron 2007, 53(4):487-493.
82. Villalobos $C$, Andrade R: Visinin-like neuronal calcium sensor proteins regulate the slow calcium-activated afterhyperpolarizing current in the rat cerebral cortex. J Neurosci 2010, 30(43):14361-14365.

83. O'Callaghan DW, Tepikin AV, Burgoyne RD: Dynamics and calciumsensitivity of the $\mathrm{Ca}^{2+}$-myristoyl switch protein hippocalcin in living cells. J Cell Biol 2003, 163:715-721.

84. Dovgan AV, Cherkas VP, Stepanyuk AR, Fitzgerald DJ, Haynes LP, Tepikin AV, Burgoyne RD, Belan PV: Decoding glutamate receptor activation by the Ca sensor protein hippocalcin in rat hippocampal neurons. Eur I Neurosci 2010, 32(3):347-358.

85. Lin L, Jeanclos EM, Treuil M, Braunewell K-H, Gundelfinger ED, Anand R: The calcium sensor protein visinin-like protein-1 modulates the surface expression and agonist sensitivity of the $\alpha 4 \beta 2$ nicotinic acetylcholine receptor. J Biol Chem 2002, 277:41872-41878.

86. Zhao CJ, Noack C, Brackmann M, Gloveli T, Maelicke A, Heinemann U, Anand R, Braunewell KH: Neuronal Ca2+ sensor VILIP-1 leads to the upregulation of functional alpha4beta2 nicotinic acetylcholine receptors in hippocampal neurons. Molecular and cellular neurosciences 2009. 40(2):280-292

87. Chaumont S, Compan V, Toulme E, Richler E, Housley GD, Rassendren F, Khakh BS: Regulation of $\mathrm{P} 2 \mathrm{X} 2$ receptors by the neuronal calcium sensor VILIP1. Sci Signal 2008, 1(41):ra8.

88. Li C, Pan W, Braunewell KH, Ames JB: Structural Analysis of Mg2+ and Ca2 + Binding, Myristoylation, and Dimerization of the Neuronal Calcium Sensor and Visinin-like Protein 1 (VILIP-1). J Biol Chem 2011 286(8):6354-6366.

89. Wang CK, Simon A, Jessen CM, Oliveira CL, Mack L, Braunewell KH, Ames JB, Pedersen JS, Hofmann A: Divalent cations and redox conditions regulate the molecular structure and function of visinin-like protein-1. PLOS ONE 2011, 6(11):e26793.

90. DeMaria CD, Soong TW, Alselkhan BA, Alvania RS, Yue DT: Calmodulin bifurcates the local $\mathrm{Ca}^{2+}$ signal that modulates $\mathrm{P} / \mathrm{Q}$-type $\mathrm{Ca}^{2+}$ channels. Nature 2001, 411:484-489.

91. Lee A, Zhou H, Scheuer T, Catterall WA: Molecular determinants of $\mathrm{Ca}^{2}$ +/calmodulin-dependent regulation of $\mathrm{Ca}(\mathrm{v}) 2.1$ channels. Proc Natl Acad Sci USA 2003, 100(26):16059-16064.

92. Nanou E, Martinez GQ, Scheuer T, Catterall WA: Molecular determinants of modulation of Cav2.1 channels by visinin-like protein 2. J Biol Chem 2011

93. An WF, Bowlby MR, Bett M, Cao J, Ling HP, Mendoza G, Hinson JW, Mattsson Kl, Strassle BW, Trimmer JS, et al: Modulation of A-type potassium channels by a family of calcium sensors. Nature 2000 , 403(6769):553-556

94. Buxbaum JD, Choi EK, Luo YX, Lilliehook C, Crowley AC, Merriam DE, Wasco W: Calsenilin: A calcium-binding protein that interacts with the presenilins and regulates the levels of a presenilin fragment. Nature Medicine 1998, 4(10):1177-1181.

95. Carrion AM, Link WA, Ledo F, Mellstrom B, Naranjo JR: DREAM is a $\mathrm{Ca}^{2}$ ${ }^{+}$-regulated transcriptional repressor. Nature 1999, 398:80-84.

96. Pruunsild P, Timmusk T: Structure, alternative splicing, and expression of the human and mouse KCNIP gene family. Genomics 2005, 86(5):581-593.

97. Shibata R, Misonou H, Campomanes CR, Anderson AE, Schrader LA Doliveira LC, Carroll KI, Sweatt JD, Rhodes KJ, Trimmer JS: A fundamental role for KChIPs in determining the molecular properties and trafficking of Kv4.2 potassium channels. J Biol Chem 2003, 278:36445-36454.

98. Venn N, Haynes LP, Burgoyne RD: Specific effects of KChIP3/calsenilin/ DREAM but not KChIPs1, 2 and 4 on calcium signalling and regulated secretion in PC12 cells. Biochem J 2008, 413:71-80.

99. Hasdemir B, Fitzgerald DJ, Prior IA, Tepikin AV, Burgoyne RD: Traffic of Kv4 $\mathrm{K}+$ channels mediated by KChIP1 is via a novel post-ER vesicular pathway. J Cell Biol 2005, 171:459-469.

100. Holmqvist MH, Cao J, Hernandez-Pineda R, Jacobson MD, Carroll KI, Sung MA, Betty M, Ge P, Gilbride KJ, Brown ME, et al: Elimination of fast inactivation in Kv4 A-type potassium channels by an auxiliary subunit domain. Proc Natl Acad Sci USA 2002, 99:1035-1040.

101. Jerng HH, Pfaffinger PJ: Multiple Kv channel-interacting proteins contain an $\mathrm{N}$-terminal transmembrane domain that regulates $\mathrm{Kv} 4$ channel trafficking and gating. J Biol Chem 2008, 283(51):36046-36059.

102. Liang P, Wang H, Chen H, Cui Y, Gu L, Chai J, Wang K: Structural Insights into KChIP4a Modulation of Kv4.3 Inactivation. J Biol Chem 2009. 284(8):4960-4967. 
103. Schwenk J, Zolles G, Kandias NG, Neubauer I, Kalbacher H, Covarrubias M, Fakler B, Bentrop D: NMR analysis of KChIP4a reveals structural basis for control of surface expression of Kv4 channel complexes. J Biol Chem 2008, 283(27):18937-18946.

104. Anderson D, Mehaffey WH, Iftinca M, Rehak R, Engbers JD, Hameed S, Zamponi GW, Turner RW: Regulation of neuronal activity by Cav3-Kv4 channel signaling complexes. Nat Neurosci 2010, 13(3):333-337.

105. Thomsen MB, Wang C, Ozgen N, Wang HG, Rosen MR, Pitt GS: Accessory subunit KChIP2 modulates the cardiac L-type calcium current. Circ Res 2009, 104(12):1382-1389.

106. Cheng H-YM, Pitcher GM, Laviolette SR, Whishaw IQ, Tong KI, Kockeritz LK, Wada T, Joza NA, Crackower M, Goncalves J, et al: DREAM is a critical transcriptional repressor for pain modulation. Cell 2002, 108:31-43.

107. Lilliehook C, Bozdagi O, Yao J, Gomez-Ramirez M, Zaidi NF, Wasco W, Gandy S, Santucci AC, Haroutunian V, Huntley GW, et al: Altered A $\beta$ formation and long-term potentiation in a calsenilin knock-out. $J$ Neurosci 2003, 23:9097-9106.

108. Mellstrom B, Savignac M, Gomez-Villafuertes R, Naranjo JR: Ca2+-operated transcriptional networks: molecular mechanisms and in vivo models. Physiol Rev 2008, 88(2):421-449.

109. Scsucova S, Palacios D, Savignac M, Mellstrom B, Naranjo JR, Aranda A: The repressor DREAM acts as a transcriptional activator on Vitamin D and retinoic acid response elements. Nucl Acids Research 2005, 33:2269-2279.

110. Ledo F, Kremer L, Mellstrom B, Naranjo JR: Ca2+-dependent block of CREB-CBP transcription by repressor DREAM. EMBO J 2002, 21(17):4583-4592.

111. Zaidi NF, Kuplast KG, Washicosky KJ, Kajiwara Y, Buxbaum JD, Wasco W: Calsenilin interacts with transcriptional co-repressor C-terminal binding protein(s). J Neurochem 2006, 98(4):1290-1301.

112. Tandon A, Fraser P: The presenilins. Genome Biol 2002, 3(11):reviews3014.

113. Leissring MA, Yamasaki TR, Wasco W, Buxbaum JD, Parker JD, LaFerla FM: Calsenilin reverses presenilin-mediated enhancement of calcium signalling. Proc Natl Acad Sci USA 2000, 97(15):8590-8593.

114. Fedrizzi L, Lim D, Carafoli E, Brini M: Interplay of the Ca2+-binding protein DREAM with presenilin in neuronal Ca2+ signaling. J Biol Chem 2008, 283(41):27494-27503.

115. Jo D-G, Jang J, Kim B-J, Lundkvist J, Jung Y-K: Overexpression of calsenilin enhances $\gamma$-secretase activity. Neuroscience letters 2004, 378:59-64.

116. Jang C, Choi JK, Na YJ, Jang B, Wasco W, Buxbaum JD, Kim YS, Choi EK: Calsenilin regulates presenilin 1/gamma-secretase-mediated $\mathrm{N}$-cadherin \{varepsilon\}-cleavage and beta-catenin signaling. FASEB J 2011, 25(12):4174-4183.

117. Fontan-Lozano A, Romero-Granados R, del-Pozo-Martin Y, Suarez-Pereira I, Delgado-Garcia JM, Penninger JM, Carrion AM: Lack of DREAM protein enhances learning and memory and slows brain aging. Curr Biol 2009, 19(1):54-60.

118. Alexander JC, McDermott CM, Tunur T, Rands V, Stelly C, Karhson D, Bowlby MR, An WF, Sweatt JD, Schrader LA: The role of calsenilin/DREAM/ KChIP3 in contextual fear conditioning. Learn Mem 2009, 16(3):167-177.

119. Wu LJ, Mellstrom B, Wang H, Ren M, Domingo S, Kim SS, Li XY, Chen T, Naranjo JR, Zhuo M: DREAM (Downstream Regulatory Element Antagonist Modulator) contributes to synaptic depression and contextual fear memory. Mol Brain 2010, 3:3.

120. Zhang Y, Su P, Liang P, Liu T, Liu X, Liu XY, Zhang B, Han T, Zhu YB, Yin DM, et al: The DREAM protein negatively regulates the NMDA receptor through interaction with the NR1 subunit. J Neurosci 2010, 30(22):7575-7586.

121. River-Arconada I, Benedet T, Roza C, Torres B, Barrio J, Krzyzanowska A, Avendano C, Mellstrom B, Lopez-Garcia JA, Naranjo JR: DREAM regulates BDNF-dependent spinal sensitization. Mol Pain 2010, 6(1):95

122. Xiong $H$, Xia K, Li B, Zhao G, Zhang Z: KChIP1: a potential modulator to GABAergic system. Acta Biochim Biophys Sin (Shanghai) 2009, 41(4):295-300.

123. Xia $K$, Xiong $H$, Shin $Y$, Wang D, Deerinck T, Takahashi H, Ellisman MH, Lipton SA, Tong G, Descalzi G, et al: Roles of KChIP1 in the regulation of GABA-mediated transmission and behavioral anxiety. Mol Brain 2010, $3: 23$.

124. Li H, Guo W, Mellor RL, Nerbonne JM: KChIP2 modulates the cell surface expression of Kv1.5-encoded $\mathrm{K}^{+}$channels. J Mol Cell Cardiol 2005, 39:121-132.
125. Rhodes KJ, Carroll KI, Sung MA, Doliveira LC, Monaghan MM, Burke SL, Strassle BW, Buchwalder L, Menegola M, Cao J, et al: KChIPs and Kv4asubunits as integral components of A-type potassium channels in mammalian brain. J Neurosci 2004, 24:7903-7915.

126. Dabrowska J, Rainnie DG: Expression and distribution of Kv4 potassium channel subunits and potassium channel interacting proteins in subpopulations of interneurons in the basolateral amygdala. Neuroscience 2010, 171(3):721-733.

127. Norris AJ, Foeger NC, Nerbonne JM: Interdependent roles for accessory KChIP2, KChIP3, and KChIP4 subunits in the generation of Kv4-encoded IA channels in cortical pyramidal neurons. J Neurosci 2010, 30(41):13644-13655.

128. Bourdeau ML, Laplante I, Laurent CE, Lacaille JC: KChIP1 modulation of Kv4.3-mediated A-type $\mathrm{K}(+)$ currents and repetitive firing in hippocampal interneurons. Neuroscience 2011, 176:173-187.

129. Norris AJ, Foeger NC, Nerbonne JM: Neuronal voltage-gated K+ (Kv) channels function in macromolecular complexes. Neuroscience letters 2010, 486(2):73-77.

130. Rivas M, Villar D, Gonzalez P, Dopazo XM, Mellstrom B, Naranjo JR: Building the DREAM interactome. Sci China Life Sci 2011, 54(8):786-792.

131. Ames JB, Lim S: Molecular structure and target recognition of neuronal calcium sensor proteins. Biochim Biophys Acta 2011.

132. Ames JB, Ishima R, Tanaka T, Gordon JI, Stryer L, Ikura M: Molecular mechanics of calcium-myristoyl switches. Nature 1997, 389:198-202.

133. Zhou W, Qian Y, Kunjilwar K, Pfaffinger PJ, Choe S: Structural insights into the functional interaction of KChIP1 with shal-type $\mathrm{K}^{+}$channels. Neuron 2004, 41:573-586.

134. Scannevin RH, Wang K-W, Jow F, Megules J, Kospco DC, Edris W, Carroll KC, $\mathrm{Lu} \mathrm{Q}, \mathrm{Xu} \mathrm{W}, \mathrm{Xu}$ Z, et al: Two N-terminal domains of Kv4 $\mathrm{K}^{+}$channels regulate binding to and modulation by KChIP1. Neuron 2004, 41:587-598.

135. Lusin JD, Vanarotti M, Li C, Valiveti A, Ames JB: NMR Structure of DREAM: Implications for $\mathrm{Ca}(2+)$-Dependent DNA Binding and Protein Dimerization(,). Biochemistry 2008, 47(8):2252-2264

136. Haynes LP, Burgoyne RD: Unexpected tails of a $\mathrm{Ca}^{2+}$ sensor. Nat Chem Biol 2008, 4(2):90-91

137. Tanaka T, Ames JB, Harvey TS, Stryer L, Ikura M: Sequestration of the membrane targeting myristoyl group of recoverin in the calcium-free state. Nature 1995, 376:444-447.

138. Spilker C, Dresbach T, Braunewell K-H: Reversible translocation and activity-dependent localisation of the calcium-myristoyl switch protein VILIP-1 to different membrane compartments in living hippocampal neurons. J Neurosci 2002, 22(7331-7339).

139. Spilker C, Braunewell K-H: Calcium-myristoyl switch, subcellular localisation, and calcium-dependent translocation of the neuronal calcium sensor protein VILIP-3, and comparison with VILIP-1 in hippocampal neurons. Mol Cell Neurosci 2003, 24:766-778.

140. Lim S, Strahl T, Thorner J, Ames JB: Structure of a $\mathrm{Ca}^{2+}$-myristoyl switch protein that controls activation of a phosphatidylinositol 4-kinase in fission yeast. J Biol Chem 2011, 286(14):12565-12577.

141. Schroder T, Lilie H, Lange C: The myristoylation of guanylate cyclaseactivating protein- 2 causes an increase in thermodynamic stability in the presence but not in the absence of $\mathrm{Ca}^{2+}$. Protein Sci 2011, 20(7):1155-1165

142. Strahl T, Huttner IG, Lusin JD, Osawa M, King D, Thorner J, Ames JB: Structural insights into activation of phosphatidylinositol 4-kinase (pik1) by yeast frequenin (Frq1). J Biol Chem 2007, 282(42):30949-30959.

143. Pioletti M, Findeisen F, Hura GL, Minor DL: Three-dimensional structure of the KChIP1-Kv4.3 T1 complex reveals a cross-shaped octamer. Nature Struct Mol Biol 2006, 13:987-995.

144. Wang H, Yan Y, Liu Q, Huang Y, Shen Y, Chen L, Chen Y, Yang Q, Hao Q, Wang $\mathrm{K}$, et al: Structural basis for modulation of $\mathrm{Kv} 4 \mathrm{~K}^{+}$channels by auxiliary KChIP subunits. Nat Neurosci 2007, 10(1):32-39.

145. Lian LY, Pandalaneni SR, Patel P, McCue HV, Haynes LP, Burgoyne RD: Characterisation of the Interaction of the C-Terminus of the Dopamine D2 Receptor with Neuronal Calcium Sensor-1. PLOS ONE 2011, 6(11): e27779.

146. Woll MP, De Cotiis DA, Bewley MC, Tacelosky DM, Levenson R, Flanagan JM: Interaction between the D2 Dopamine Receptor and Neuronal Calcium Sensor-1 analyzed by fluorescence anisotropy. Biochemistry 2011, 50:8780-8791. 
147. Heidarsson PO, Bjerrum-Bohr IJ, Jensen GA, Pongs O, Finn BE, Poulsen FM, Kragelund BB: The C-terminal Tail of Human Neuronal Calcium Sensor 1 Regulates the Conformational Stability of the $\mathrm{Ca}^{2+}$-Activated State. J Mol Biol 2012.

148. Zernii E, Komolov K, Permyakov S, Kolpakova T, Dell Orco D, Poetzsch A, Knyazeva E, Grigoriev I, Permyakov E, Senin I, et al: Involvement of recoverin C-terminal segment in recognition of the target enzyme rhodopsin kinase. Biochem J 2011, 435:441-450.

149. Bourne $Y$, Dannenberg J, Pollmann V, Marchot P, Pongs O:

Immunocytochemical localisation and crystal structure of human frequenin (neuronal calcium sensor 1). J Biol Chem 2001, 276:11949-11955.

doi:10.1186/1756-6606-5-2

Cite this article as: Burgoyne and Haynes: Understanding the physiological roles of the neuronal calcium sensor proteins. Molecular Brain 2012 5:2.

\section{Submit your next manuscript to BioMed Central} and take full advantage of:

- Convenient online submission

- Thorough peer review

- No space constraints or color figure charges

- Immediate publication on acceptance

- Inclusion in PubMed, CAS, Scopus and Google Scholar

- Research which is freely available for redistribution

Submit your manuscript at www.biomedcentral.com/submit 